\title{
EPS Library
}

National Cancer Institute

\section{Source}

National Cancer Institute. EPS Library. NCI Thesaurus. Code C15804.

Library located at Executive Plaza South. 